\title{
PERAN BANK SAMPAH DALAM MENINGKATKAN PENDAPATAN EKONOMI IBU-IBU RUMAH TANGGA
}

\author{
Mulyadi $^{1)}$, Ridwan Wahyudi' ${ }^{2 *}$, Ika Swasti Putri ${ }^{3)}$ \\ STIE Adi Unggul Bhirawa Surakarta \\ *Emai: ridwan@stie-aub.ac.id
}

\begin{abstract}
ABSTRAK
Pengabdian masyarakat ini dilakukan di Kecamatan Banjarsari, Kota Surakarta, pelaksanaan kegiatan pengabdian kepada masyarakat bertempat di Bank Sampah Kampung Minapadi RW IX, Kalurahan Nusukan. Waktu pelaksanaan pada hari Minggu, 15 Desember 2019. Sebanyak 23 peserta yang terdiri dari ibu-ibu rumah tangga melakukan partisipasi dalam kegiatan ini. Kegiatan pengabdian masyarakat ini terdiri dari tiga tahapan yang meliputi pemberian materi, diskusi, dan praktik cara pengelolaan bank sampah untuk meningkatkan ekonomi ibu-ibu rumah tangga.

Metode yang digunakan dalam program ini adalah pendampingan tentang pengelolaan Bank Sampah, penyuluhan dan pelatihan pengelolaan sampah, sebagai potensi peningkatan ekonomi masyarakat di Kecamatan Banjarsari.
\end{abstract}

Kata Kunci : Pengelolaan Bank Sampah, Peran Bank Sampah

\section{A. ANALISA SITUASI}

Belakangan ini, masyarakat Indonesia mulai sadar bahwa sampah bukan lagi sebagai sebuah musuh yang harus dihindari, melainkan bisa berubah menjadi berkah yang mampu memperbaiki perekonomian bangsa. Berbagai macam inovasi pengolahan sampah terus dikembangkan, mulai dari mengubah sampah organik menjadi pupuk kompos, hingga pembentukan bank sampah yang bisa menjadi alternatif untuk mengumpulkan pundi-pundi uang. Konsep terakhir yang disebut tampaknya tengah bersinar di kalangan masyarakat dalam 4 tahun terakhir dan sedang digarap serius oleh pemerintah supaya bisa menyelesaikan dua persoalan bangsa: kebersihan dan kemiskinan. Potret keberhasilan dari konsep bank sampah ini akan dirasakan langsung oleh ibu-ibu di Kecamatan Banjarsari.

Pendapaan kepala keluaraga yang terbatas sering menjadi sumber konflik/masalah ekonomi dapat dikurangi dengan cara pengelolaan keuangan keluarga yang baik dan peran ibu rumah tangga yang biasanya menjalankan peranannya sebagai manajer keuangan didalam keluarga menjadi sangat penting. Namun, seringkali para ibu rumah tangga mengelola keuangan dengan sembarangan atau seadanya sehigga akhirnya menimbulkan masalah yang cukup serius di dalam keluarga. Kondisi inilah yang banyak terjadi di kalangan ibu rumah tangga di Kecamatan Banjarsari Kota Surakarta.

Minimnya keberadaan dan kepedulian organisasi atau lembaga yang berada di sekitar lokasi untuk pengembangan ibu-ibu rumah tangga di Kecamatan Banjarsari masih kurang mampu untuk membantu para ibu dalam mengelola keuangan dengan baik.

Dari survey awal, tim berhasil mendapatkan data sekitar 60 Kepala Keluarga yang sampling bermukim didaerah tersebut. Sehingga dapat dipastikan 50\% atau sekitar 30 orang adalah ibu rumah tangga yang hampir 80\% tidak bekerja dengan kisaran usia antara 25-60 tahun. Dengan profil yang telah disebutkan diatas dan kondisi mereka dalam pengelolaan keuangan keluarga masih jauh dari standar yang baik maka kami ingin membantu melakukan pengembangan perempuan di daerah Kecamatan Banjarsari terutama dalam hal meningkatkan pendapatan ibu rumah tangga di daerah tersebut.

Saat ini bank sampah merupakan suatu wadah yang dapat digunakan banyak pihak untuk meningkatkan kesadaran masyarakat terhadap gaya hidup yang lebih bersih dan sehat serta mampu 
meningkatkan pendapatan ibu rumah tangga. Tujuan inilah yang menarik bagi kalangan menengah kebawah yang masih memiliki masalah tingkat ekonomi.

\section{B. KERANGKA PEMECAHAN MASALAH}

Tim Pengabdian kepada masyarakat STIE-AUB Surakarta setelah melakukan pengamatan di lapangan ternyata sebagian besar warga Kecamatan Banjarsari, Surakarta belum tahu tentang peran bank sampah terhadap peningkatan pendapatan ekonomi, sehingga diperlukan sosialisasi untuk memberikan pengetahuan bagi mereka tentang peran dan metode dalam peningkatan pendapatan ekonomi dengan pemecahan masalah sebagai berikut:

1. Membentuk pengurus

Organisasi ini bertujuan untuk pengelolaan sampah. Terlibatnya banyak pihak atau orang merupakan esensi dari pembentuk organisasi ini. Individu pada perkumpulan ini pada umumnya yang perduli dengan lingkungan hidup. Merupakan penduduk yang sudah lama menetap sehingga pada penyusunan anggota pengurus dapat memberikan usulan-usulan. Susunan organisasi umum yang biasa digunakan dalam bank sampah Ketua, Sekretaris, Bendahara, Koordinator dan anggota.

2. Membentuk penamaan bank sampah

Nama merupakan suatu hal yang penting dalam sebuah organisasi. Diperlukan kepeutusan bersama dalam pembuatan nama ini agar identitas tersebut dapat digunakan secara berkesinambungan bersama-sama.

Disarankan dalam penamaan bank sampah diperlukan nama-nama yang sesuai dengan tema lingkungan hidup sehingga mudah dikenal dan diingat oleh masyarakat. Banyak pilihan nama dalam organisasi ini, pada intinya organisasi ini juga merupakan organisasi profit yang wajib menguntungkan semua anggotanya sehingga target-target perencanaan organisasi perlu untuk dilakukan.

Menggunakan kaidah targeting perusahaan profit pada umumnya. Penentuan target bukan merupakan suatu yang harus benar-benar terjadi, pada intinya agar anggota dapat jeli melihat penumpukan sampah baik terjadwal maupun tidak terjadwa. Misalnya, dalam sesia acara pernikahan dan lain sebagainya ada sampah-sampah makan yang ada di tangan kita sendiri agar kita kelola. Untuk yang tidak terjadwal sampah pinggir jalan pada saat melintas.

3. Tempat

Tempat pelaksanaan kegiatan. Setelah pengurus dibentuk dan juga nama organisasi telah disepakati. Telah ada Anggaran Dasar atau Anggaran Rumah Tangga ditetapkan. Diperlukan tempat. Tempat ini sebagai kantor administratif bank sampah. Tempat melakukan transaksi penimbangan sampah yang masuk serta administrasi keanggotaaan yang baru.

Bank sampah awalnya lebih baik dibuat di tempat rumah pribadi salah satu pengurus karena belum terdapat omset usaha disini. Bila organisasi ini dapat berjalan produktif dan berkesinambungan organsisasi dapat membangun sebuat shelter perkantoran administrasi dan masuknya barang-barang sampah.

4. Kerja sama dengan Pengepul rongsok

Untuk membangun kerja sama dengan pelaku UMKM rongsokan dan pengepul bank sampah harus membangun kerja sama. Bank sampah dengan pengepul setempat, bila bank sampah sudah dapat mengupdate harga-harga rongsok seperti plastik, besi, dan lain sebagainya bank sampah wajib melakukan kerja sama dengan pengepul yang memberikan tawaran harga menarik.

Dengan gross profit margin (GPM) yang sesuai dapat memberikan keuntungan yang cukup untuk organisasi ini. 
5. Alat operasional

Peralatan dalam menjalankan bank sampah tidak banyak. Hanya diperlukan timbangan baik timbangan gantung maupun duduk. Karung beras untuk melakukan pensortiran terhadap barang yang masuk. Untuk perkembangan selanjutnya organisasi ini dapat melakukan penyediaan motor, atau motor roda tiga dan mobil bak terbuka untuk pengangkutan sampah bila sudah banyak.

Karung tersebut diberkan label sesuai dengan jenis sampahnya. Untuk administrasi anggota yang menyetorkan sampah dapat dilakukan berdasarkan nama penyetor dan juga jenis sampah serta berat timbangannya. Dari administrasi tersebut anggota dapat melihat berapa besar tabungannya di bank sampah itu.

6. Administrasi

Bank sampah mirip dengan bank konvensional atau perbankan mikro pada umumnya. Pengelolaan sampah memerukan administrasi dan setoran sampah kepada organsasi sedangkan kredit adalah untuk pembayaran yang dilakukan organisasi terhadap anggota.

Pembukuan administratif lainnya berupa buku tabungan, buku induk nasabah (Customer Information File - CIF) liha Istilah Perbankan dan Mikro, buku rekapitulasi penimbangan, buku kas, buku tamu dan lain-lain.

7. Menentukan jadwal kegiatan

Jadwal kegiatan lebih bermaksud kepada pembangunan motivasi para anggota karena usaha ini hampir mirip dengan tukang sampah sehingga diperlukan pembentukan komitmen dalam membangun roda bisnis organisasi.

Anggota wajib melakukan sharing knowledge dalam jadwal kegiatan tersebut. Dengan motivasi masing-masing pengelolaan sampah tersebut. Siklus usaha ini disarankan untuk dijalankan setiap hari dengan mengambil waktu-waktu senggang anggota dalam melakukan setoran. Dan pengurus organisasi merupakan individu dengan kegiatan yang hanya dilakukan sampai sore seperti Pegawai kelurahan, Guru dan PNS tidak sampai malam hari seperti pegawai swasta, pegawai bank dll.

8. Sosialisasi

Sosialisasi bank sampah kepada masyarakat melalui media fisik maupuk non fisik. Dengan pamflet dan juga brosur-brosur atau lewat non fisik melalui media sosial seperti banksampah.id. Hal tersebut untuk mengundang banyaknya partisipan atau anggota baru yang tertarik dalam menjalankan roda organisasi bank sampah.

\section{SOLUSI YANG DITAWARKAN}

Menyadari terhadap potensi dan permasalahan yang telah diuraikan diatas, maka diperlukan adanya kegiatan atau pelatihan yang mampu untuk memecahkan permasalahan yang berkaitan diatas, solusi permasalahan tersebut dapat diuraikan sebagai berikut:

a. Menjelaskan metode pengelolaan bank sampah.

b. Meyalurkan ilmu pengetahuan terhadap para warga masyarakat di Kecamatan Banjarsari Surakarta tentang metode pengelolaan bank sampah.

c. Pembinaan secara optimal atas metode pengelolaan bank sampah di Kampung Minapadi Kal. Nusukan Surakarta. 


\section{KHALAYAK SASARAN}

Ibu-ibu rumah tangga di Kecamatan Banjarsari Surakarta.

\section{E. METODE PELAKSANAAN}

Kegiatan ini akan dilakukan dengan metode:

a. Ceramah: memberikan penjelasan secara langsung dari pada materi dengan menggunakan makalah kepada ibu-ibu rumah tangga di Kecamatan Banjarsari Surakarta.

b. Pelatihan: memberikan pemahaman kepada ibu-ibu rumah tangga untuk dapat mengelola bank sampah.

c. Sarasehan : memberikan ceramah, penyuluhan dan pelatihan beberapa hari untuk sampai mendapatkan pemahaman yang baik bagi ibu-ibu rumah tangga di Kecamatan Banjarsari Surakarta.

d. Pendampingan : melakukan pendampingan pada saat ada kesulitan dalam metode pengelolaan bank sampah.

\section{F. PEMBAHASAN}

Sesuai dengan rencana yang telah ditentukan sebelum kegiatan pelatihan dilaksanakan, kegiatan ini diawali dengan penyiapan berbagai administrasi diperlukan antara lain permohonan ijin melaksanakan pengabdian masyarakat, undangan peserta pelatihan, koordinasi untuk waktu dan tempat pelatihan, penyiapan materi pelatihan tentang pengelolaan bank sampah serta penyiapan jadwal pelatihan. Berikut ini akan diuraikan hasil yang dicapai terkait dengan pelatihan tata cara pengelolaan bank sampah di Kecamatan Banjarsari:

1. Peserta Pelatihan

Peserta yang hadir dalam pelatihan ini adalah sejumlah 23 peserta terdiri dari ibu-ibu rumah tangga dan tokoh masyarakat di Kecamatan Banjarsari Surakarta. Kegiatan ini diawali dengan sambutan ketua RT setempat, dilanjutkan dengan penyampaian metode pengelolaan bank sampah untuk meningkatkan pendapatan ibu-iu rumah tangga.

2. Penyiapan Materi

Materi yang disiapkan pada pelatihan ini meliputi pengertian bank sampah, metode pengelolaan bank sampah, manajemen dan peran bank sampah untuk meningkatkan pendapatan. Materi tersebut disiapkan dalam bentuk Power-point, dan dalam bentuk soal-soal kasus.

3. Kegiatan Pelatihan

Kegiatan pelatihan ini dilaksanakan tgl 15 Desember 2019 bertempat di Kampung Minapadi, Kal. Nusukan, Kecamatan Banjarsari Surakarta. Kegiatan pelatihan ini terdiri dari tiga tahapan yang meliputi pemberian materi, diskusi, dan praktik cara pengelolaan bank sampah.

4. Pemberian Materi

Pemberian materi pelatihan ini berlangsung selama 2 jam. Materi yang disampaikan antara lain pengertian bank sampah, metode pengelolaan bank sampah, manajemen dan peran bank sampah untuk meningkatkan pendapatan.

5. Diskusi

Setelah penyampain materi diakhiri kemudian dilanjutkan dengan diskusi, diskusi ini 
berlangsung dengan tertib dan terarah. Pada saat diskusi peserta berperan aktif bertanya terkait dengan permasalahan yang mereka hadapi sebelum menglola bank sampah.

6. Pendampingan

Pendampingan dilakukan dalam kurun waktu 6 bulan setelah menerapkan pengelolaan bank sampah berbasis peningkatan ekonomi dilakukan monitoring terhadap kinerja pengurus apakah sudah sesuai dengan metode pengelolaan bank sampah yang baik dan efisien.

A. Pembahasan

1. Pengertian Bank Sampah

Definisi Bank Sampah menurut Peraturan Menteri Lingkungan Hidup RI Nomor 13 Tahun 2012 adalah tempat pemilahan dan pengumpulan sampah yang dapat didaur ulang dan/atau diguna ulang yang memiliki nilai ekonomi. Dari pengertian diatas menunjukkan bahwasanya Bank Sampah merupakan suatu institusi ataupun tempat pemilahan/pengumpulan sampah yang dibentuk untuk mengelola dan memaksimalkan nilai sampah dengan prinsip $3 \mathrm{R}$ melalui pendekatan berbasiskan masyarakat.

Menurut Astuti, N.A. 2013 menyatakan bahwa pengertian bank sampah Yaitu suatu unit kerja yang melakukan pengelolaan sampah dimana kegiatannya meliputi pemilahan sampah dari sumbernya yang kemudian dikumpulkan pada suatu tempat kemudian dijual ke pihak ketiga. Bank Sampah dibuat dengan menerapkan Undang-Undang Nomor 18 Tahun 2008 Tentang Pengelolaan Sampah bahwa prinsip pengelolaan sampah adalah reduce, reuse, dan recycle yaitu mengurangi, menggunakan kembali dan mengolah sampah.

2. Pengelolaan Bank sampah.

Bank sampah sesungguhnya mudah untuk dikelola.Untuk membentuk suatu bank untuk menabung sampah-sampah di lingkungan Anda, dan warga sekitar dapat menunjuk beberapa orang sebagai petugas pengelola. Dibutuhkan minimal orang untuk menjadi petugas pencatat administrasi keuangan, satu orang untuk menjadi petugas pengelola tabungan, dan satu orang sebagai petugas pengelola sampah (perantara pengepul). Selanjutnya, masing-masing petugas memiliki tersendiri. Perantara pengepul bertugas melakukan

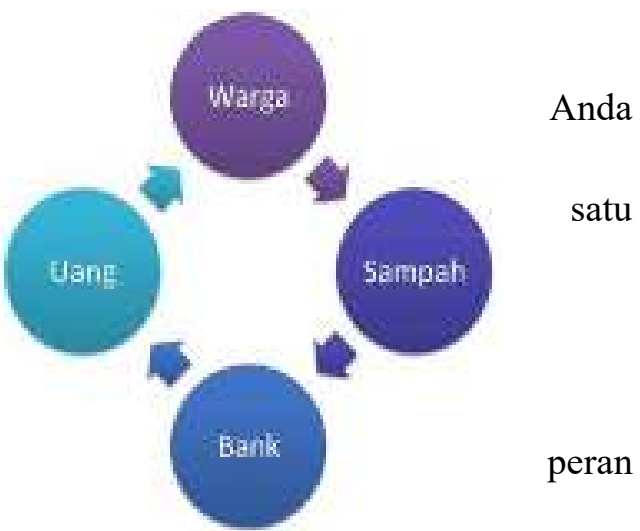
negosiasi dengan pengepul dan mengawasi proses pengepulan sampah. Pengelola administrasi keuangan akan bekerja sama dengan perantara pengepul untuk mencatat hasil sampah masingmasing warga.

Sedangkan pengelola tabungan bertugas untuk menyetorkan tabungan masing-masing warga ke bank dan nantinya dia jugalah yang bertugas untuk mengambil uangnya di bank jika ada warga yang hendak mengambil tabungannya.

Dalam pengaplikasiannya, bank sampah akan lebih mudah dikelola jika proses pengepulan sampah terjadwal dengan baik. Misalnya, warga dapat atau diwajibkan menyetorkan sampah anorganik yang telah dikumpulkannya dari sisa-sisa atau sampah rumah tangga setiap satu minggu sekali. Dengan begitu, sampah yang terkumpul akan lebih banyak dan uang yang didapat pun lebih banyak. Jika bank sampah yang ada dilingkungan Anda sudah memiliki administrasi yang baik dan sudah mampu bekerja dengan baik, kualitasnya dapat ditambahkan dengan adanya kepemilikan 
badan hukum dan buku tabungan sendiri. Dengan demikian, bank pengelola sampah di lingkungan Anda akan lebih berprospek secara ekonomi.

Keberadaan bank sampah dinilai akan lebih meningkatkan kesadaran masyarakat akan pentingnya pengelolaan sampah di lingkungannya masing-masing. Sampah terutama sampah anorganik sejatinya dapat dijadikan sumber rupiah. Dengan adanya fasilitas pengelolaan sampah mandiri, diharapkan masyarakat akan lebih giat untuk mengelola sampahnya masing-masing dan mau menjaga kebersihan lingkungannya dengan baik.

Pengelolaan sampah tidak melulu harus dilakukan oleh pihak-pihak yang berwenang.Pengelolaan sampah dapat dan wajib dilakukan oleh kita semua. Mengelola sampah secara mandiri akan mendatangkan banyak manfaat bagi diri kita sendiri maupun lingkungan sekitar kita.

Pengelolaan Bank sampah mirip dengan pada bank umum lainnya. Setiap nasabah datang dengan lima kantong sampah yang berbeda. Kantong yang berisi :

1. Kantong 1 berisi sampah organik

2. Kantong 2 berisi sampah plastic

3. Kantong 3 berisi sampah kertas

4. Kantong 4 berisi sampah botol

5. Kantong 5 berisi sampah kaleng

Pengelolaan Bank Sampah juga mengikuti kaidah-kaidah yang terdapat dalam Undangundang nomor 18 tahun 2008 tentang pengelolaan sampah, bahwa prinsip dalam mengelola sampah adalah reduce, reuse dan recycle (3R).

Cara pengelolaan bank sampah, yaitu:

1. Membentuk sebuah bank sampah untuk menabung sampah-sampah yang dikummpulkan di lingkungan Anda.

2. Kemudian menunjuk beberapa orang yang ada di lingkungan Anda sebagai petugas pengelola, yaitu minimal satu orang sebagai pencatat administrasi keuangan, satu orang sebagai petugas pengelola tabungan, dan satu orang petugas untuk pengelola sampah (perantara pengepul).

3. Masing-masing petugas tersebut memiliki peran sesuai tugasnya. Yaitu, perantara pengepul melakukan negosiasi dengan para pengepul serta mengawasi proses pengepulan sampah. Sedangkan petugas administrasi keuangan bekerja dengan perantara pengepul akan mencatat hasil sampah yang terkumpul dari masing-masing warga. Dan pengelola tabungan akan menyetorkan tabungan dari masing-masing warga pada sebuah bank dan tentu saja bertugas juga untuk mengambilkan uang di bank jika ada warga yang ingin mengambil tabungannya.

4. Proses pengepulan sampah harus terjadwal dengan baik, agar kerja bank sampah bisa lebih mudah dan efektif. Misalnya, warga dijadwalkan menyetorkan sampah anorganik setiap satu minggu sekali. Dengan begitu, akan lebih banyak sampah yang terkumpul dan uang yang dihasilkan pun akan lenih banyak.

5. Jika bank sampah tersebut sudah memiliki administrasi yang baik, cara kerja pengelolaan yang baik, maka kualitas bank sampah dapat ditingkatkan dengan 
menambahkan kepemilikan badan hukum dan pembuatan buku tabungan sendiri. Sehingga, bank pengelola sampah tersebut akan lebih berprospek secara ekonomi.

3. Mekanisme dan Cara Kerja Bank Sampah

1) Mekanisme Menabung Bank Sampah

Menurut Astuti, N.A. 2013 dalam (Suwerda, 2009). Mekanisme dalam menabung sampah di bank sampah ada dua, yaitu menabung sampah secara individual dan menabung sampah secara komunal. Mekanisme menabung sampah secara individual, warga memilah sampah kertas, plastik, kaleng/botol, dari rumah dan secara berkala ditabung ke bank sampah, sedangkan mekanisme menabung sampah secara komunal, warga memilah sampah kertas, plastik, kaleng/botol, dari rumah dan secara berkala ditabung di TPS (Tempat Penampungan Sementara) yang ada di tiap RT atau kelompok masyarakat (POKMAS), kemudian petugas bank sampah mengambil sampah di tiap TPS.

2) Cara Kerja Bank Sampah

Bank sampah adalah sebuah istilah yang diperuntukan bagi suatu paguyuban atau perkumpulan warga sadar sampah yang memiliki tujuan untuk mengurangi volume sampah, memanfaatkan sampah, dan menge-lolanya untuk dijadikan sumber penghasilan tambahan.Cara kerja bank sampah adalah dengan mengumpulkan sampah anorganik sebanyak-banyaknya dari lingkungan Anda sendiri.Kemudian sampah tersebut dikumpulkan ke petugas atau pengepul yang ditunjuk di lingkungan tempat tinggal Anda. Sampah tersebut nantinya akan dipilah sesuai jenisnya lalu kemudian ditimbang. Selanjutnya, sampah yang telah dipilah menurut jenisnya dan yang telah ditimbang tersebut akan ditukar dengan sejumlah uang. Nantinya Anda dapat mengambil uangnya langsung atau dapat juga ditabungkan langsung ke petugas tertunjuk di lingkungan tempat Anda tinggal.Namun, ada beberapa jenis bank sampah yang membuatkan buku tabungan untuk masing-masing anggotanya, sehingga administrasi keuangannya pun lebih transparan dan terorganisir. Bank sampah yang baik memiliki kriteria seperti memiliki badan hukum, memiliki sistem administrasi, memiliki pengepul tetap, memiliki buku tabungan, dan memiliki pihak penanggung jawab dan petugas lainnya.

a) Cara kerja bank sampah untuk lingkungan warga

- Nasabah datang ke cabang.

- Nasabah datang dan langsung menuju meja taller, di sana nanti teller kami akan memberikan lembaran kualifikasi sampah bagi calon nasabah baru.

- Setelah nasabah berminat maka nasabah bisa mengisi formulir yang diberikan oleh teller, sebagai berikut: Aplikasi pembukaan rekening sampah dana perorangan.

- Sambil nasabah mengisi form tadi, teller akan meminta KTP atau kartu pelajar yang akan dicocokan atau disamakan dengan form yang nasabah isi.

- sambil menunggu buku tabungan jadi, nasabah akan diminta tanda tangannya oleh teller pada form tanda tangan nasabah.

- Setelah itu teller akan menjelaskan tentang peraturan di bank sampah. 
- Setelah mendengarkan penjelasan pegawai bank secara singkat, lalu teller akan memberi buku tabungan kepada nasabah dengan warna buku tabungan yang berbeda sesuai dengan RT-nya.

b) Cara kerja bank sampah untuk perusahaan

- Karyawan bank sampah datang ke perusahaan untuk menjelaskan kerjasama tentang manajemen pengelolaan bank sampah, dimana kami akan menjelaskan tentang kualifikasi sampah yang bisa di tabung di bank sampah.

- Selanjutnya apabila pihak perusahaan setuju dengan kerjasama yang ditawarkan, bank sampah dan perusahaan akan membuat nota perjanjiaan, yang nantinya akan dibuat nota persetujuan bersama.

- Karyawan bank sampah akan memberikan sejumlah form yang harus diisi dari pihak perwakilan perusaan, sebagai berikut.

- Setelah persyaratan dan kerjasama telah dipahami bersama.

- Untuk kwalifikasi penempatan sampah sama dengan sampah rumah tangga dengan menggunakan plastic yang berbeda. Yang nantinya perusahaan akan menambatkan bukti penyetoran sampah dari bank sampah yang telah ditanda tangani oleh kedua belah pihak serta disaksikan dalam penghitungan bobot samapah oleh keduanya, selanjutnya akan didata dan dimasukan ke komputerisasi teller bank sampah yang di kirim oleh driver bank sampah.

- Nantinya sampah yang ada dilingkungan perusahaan akan diambil langsung oleh pegawai bank sampah dengan menggunakan mobil pick-up.

- Masalah pembayaran akan dibayar sesuai dengan perjanjiaan yang ada.

\section{G. KESIMPULAN DAN SARAN}

A. Simpulan

Dari penjelasan yang telah dipaparkan tersebut sehingga dapat ditarik kesimpulan yaitu sebagai berikut:

1. Bank sampah yaitu suatu unit kerja yang melakukan pengelolaan sampah dimana kegiatannya meliputi pemilahan sampah dari sumbernya yang kemudian dikumpulkan pada suatu tempat kemudian dijual ke pihak ketiga.

2. Dengan adanya Bank Sampah di Kecamatan Banjarsari dapat memberdayakan ekonomi masyarakat dengan cara melibatkan potensi masyarakat dalam menangani sampah yang mereka miliki melalui pemilahan dan pengelolaan sampah yang baik dan benar. Hal itu sesuai dengan prinsip-prinsip pemberdayaan masyarakat menurut Soedijantoyaitu kesukarelaan, otonom, keswadayaan, partisipatif, egaliter.

3. Bank Sampah di Kecamatan Banjarsari memberikan dampak bagi masyarakat, diantaranya sebagai tambahan pendapatan ekonomi dari program tabungan sampah dan kerajinan sampah anorganik, memberikan edukasi kepada masyarakat mengenai cara pengelolaan sampah yang baik dan benar, selain itu memberikan dampak kepada masyarakat untuk bersosialisasi antar masyarakat sehingga timbul rasa untuk saling tolong menolong seperti kegiatan sedekah sampah, dan dengan adanya Bank Sampah Adipati Mersi lingkungan menjadi bersih terbebas 
dari sampah dan meningkatnya kualitas kesehatan masyarakat dari pencemaran udara dan air yang disebabkan oleh sampah.

B. Saran

Untuk pengembangan dan membantu manajemen Bank Sampah dalam Menghasilkan Uang masa yang akan datang, yaitu:

1. Pihak Bank Sampah di Kecamatan Banjarsari sebaiknya melakukan sosialisasi terus menerus kepada masyarakat Mersi agar jumlah nasabah dan pengrajin sampah anorganik terus meningkat dan masyarakat bisa mengetahui cara mengelola sampah yang baik dan benar.

2. Bagi para pengrajin, dalam memasarkan hasil dari kerajinan sampah anorganik untuk lebih luas dan dapat diminati oleh setiap kalangan masyarakat, disarankan untuk bisa lebih aktif dalam memanfaatkan media sosial seperti facebook, instagram, dll.

3. Bagi masyarakat di Kecamatan Banjarsari, disarankan untuk lebih banyak lagi masyarakat yang berpartisipasi dalam kegiatan program Bank Sampah baik itu program tabungan sampah, kerajinan sampah anorganik ataupun sedekah sampah karena selain mendapatkan penghasilan juga dapat menjadikan lingkungan yang bersih dan sehat.

\section{DAFTAR PUSTAKA}

Anonim (2008) Undang-Undang Republik Indonesia Nomor 18 Tahun 2008 Tentang Pengelolaan Sampah

Astuti (2011) Analisis Timbunan dan Komposisi Sampah di Kelurahan Mekar Jaya (Depok) di Hubungkan Dengan Tingkat Pendapatan- Pendidikan -Pengetahuan- Sikap - Perilaku Msayarakat. Skripsi, Fakultas Teknik Lingkungan :UI

Fernando,dkk. (2015). Peran Bank Sampah Dalam Meningkatkan Pendapatam Para Ibu di Dayeuhkolot, Manggahang dan Banjaran (Bandung Selatan). http://repository.unpar.ac.id/handle/123456789/798

Mahatma Yudhi. (2015). Bank Sampah Perbaiki Ekonomi Masyarakat https://bisnis.tempo.co/read/751607/bank-sampah-perbaiki-ekonomi-masyarakat

Putri Linda I., (2011). Peranan Bank Sampah dalam Pemberdayaan Ekonomi Masyarakat (Studi Kasus pada Bank Sampah Adipati Mersi Kecamatan Purwokerto Timur Kabupaten Banyumas). Skripsi. Purwokerto: IAIN Purwokerto.

http://senangnews.com/geliat-pengelolaan-bank-sampah-di-minapadi-meningkatkan-pendapatan-ibu$\underline{\mathrm{ibu} /}$ 